\title{
The Potential of Earthworms (Lumbricus sp.) in Anrelli Village, Kulo District as an Environment- Based Biology Learning Resource
}

\author{
Muhammad Sultani Taufik ${ }^{1, *}$ Slamet Suyanto ${ }^{2,}$ Amri $^{3}$, Fadilah Dahlan ${ }^{3}$ \\ ${ }^{1}$ Master of Biology Education, Faculty of Mathematics and Natural Sciences, Universitas Negeri Yogyakarta, \\ Indonesia \\ ${ }^{2}$ Department of Biology Education, Faculty of Mathematics and Natural Sciences, Universitas Negeri \\ Yogyakarta, Indonesia \\ ${ }^{3}$ Biology Education, Faculty of Teacher Training and Education, Universitas Muhammadiyah Pare, Indonesia \\ *Corresponding author. Email: muhammadsultani.2019@student.uny.ac.id
}

\begin{abstract}
The research objective was to find out the potential of earthworms (Lumbricus sp.) in residential environments, rice fields, and cattle farms in Anrelli Village, Kulo District as an environment-based biology learning resource. The research used a descriptive study with a descriptive-qualitative research method. The research population was all Lumbricus sp., in Anrelli Village, Kulo District. The research samples were all Lumbricus sp., from three locations with an area of $1 \times 1 \mathrm{~m}$ and a depth of 0-30 cm. The supporting samples of the study were the physical, chemical, and biological soil conditions. The sampling techniques used purposive sampling with Hand-Sorting method. The data analysis technique is descriptive-qualitative with an inductive approach on the subject of Animal World in $10^{\text {th }}$ grade according to KI.3 and KD. 3.3. The supporting sample used the Morario formula. The research results were Lumbricus terrestris, Lumbricus castaneus, and Lumbricus rubellus. The earthworms morphologies that can be observed by students as learning resources are body size, skin/body surface, body-color, segments, setae, clitelium, and prostomium. These findings can be integrated as an environment-based biology learning resource by explaining the classification principles of living things in five kingdoms.
\end{abstract}

Keywords: Morphology, Lumbricus sp., Environment-based learning resources

\section{INTRODUCTION}

The success of students in learning is certainly inseparable from the role of teachers (educators) who guide and teach students in order to educate the next generation of the nation. The role of teachers in learning is as a facilitator for the success of students learning and to achieve learning objectives. Teachers as facilitators who provide learning to students are certainly inseparable from the learning resources used as part of the learning component to present an active and creative learning process so as to create a pleasant learning atmosphere. Syamsudduha [1] states that the learning environment system itself is influenced by several components that affect each other. These components are human resources, namely teachers and students, as well as learning environments and learning support devices. Mudhoffir [2], also said that learning resources are essential components of instructional systems that include messages, people, tool materials, techniques, and environments, which can affect student learning outcomes. Therefore, learning by utilizing nature as a learning resource can provide individual experiences to students and make students more independent in developing independent, capable and strong personality in achieving character education objectives as the curriculum 13.

The use of learning resources properly will support the learning process, where the learning will not be monotonous, because there is interaction between students and teachers directly. This learning process presents learning resources that make students to actively do physical activities and think thoroughly as a result of implementing relevant biological materials. Duffy and Jonassen [3], explained that the utilization of various learning resources is an effort to solve 
learning problems. Similar with Imtihana [4], that one of the factors that can influence student learning success is the utilization of learning resources. Vikagustanti [5], also explained that teachers need to choose the appropriate methods, models, learning resources, and learning media so that teaching process is more interesting and the material received by the students is not just a set of concepts. Therefore, researchers try to use a type of learning resources based on environmental utilization in three locations, namely residential areas, rice fields, and cattle farms. The environment as a learning resource will certainly give students direct experience, students no longer just imagine concepts, see the context in the form of writing and image, but students can see and identify directly if they use the environment as learning resource.

Utilization of the environment in these three locations as a form of the variant in the learning process to convey information and facts about the morphology of invertebrate animals in biology subjects. Related to the morphology of invertebrate animals, researchers make the morphological potential of earthworms (Lumbricus Sp.) as an alternative learning resource in the environment. Haryati [6], viewed in terms of potential, the environment outside the school needs to be considered as an alternative to providing variety in learning. Safei [7], this natural environment can be very effective if teachers are able to use it creatively. In addition, the utilization of the natural environment can enrich the teaching strategies of teachers. Syamsudduha [1], asserts that, several supporting factors are needed, such as learning methods in presenting materials to students. Teachers or instructor in presenting the material not only focus on the subject matter, but also help students to interact with various learning resources in obtaining knowledge, skills, abilities and attitudes that lead to changes in behavior both cognitively, affectively, and psychomotor.

Biology learning by utilizing learning resources in the environment provides emphasis and direct experience, where it will foster the competence of students social attitudes in the form of environmental care behavior, discipline, cooperation, responsibility, responsiveness, and activity. Therefore, the basis of this research is to present, in real, the natural form of learning resource in the environment with the aim of research "to know the morphological potential of earthworms (Lumbricus sp.) in residential areas, rice fields, and cattle farms in Anrelli Village, Kulo District as a learning resource". Researchers tried to describe and introduce the potential of earthworms (Lumbricus sp.) morphologies as a learning resource at senior high school in $10^{\text {th }}$ grade. This is based on students need for learning resources that students can observe directly and are faced with problems in the environment and in the community. Similar research conducted by Febrita [8], according to him the growth and development of earthworms can be used as a source of learning. Other similar research in Pangestika [9], he said efforts to increase the growth and production of Earthworm Cocoon (Lumbricus rubellus) can be used as a source of learning biology.

\section{RESEARCH METHOD}

This type of research is descriptive research. Descriptive research according to Sukmadinata [10], which is a study that describes existing phenomena, either natural or artificial. The research method uses descriptive-qualitative, which aims to identify and describe the morphology of earthworm species in three locations as an environment-based biology learning resource.

The research was conducted in Anrelli Village, Kulo District, Sidrap Regency, South Sulawesi Province in three locations, namely residential area (location I), rice fields (location II), and cattle farms (location III), as in figure 1. After that the research was continued in the Faculty of Agriculture, Animal Husbandry and Fisheries laboratory, Muhammadiyah University of Parepare which was started from June to August 2019.

The population of this study were all Earthworms (Lumbricus sp.) in Anrelli Village, Kulo District. The samples in this study were all Earthworms (Lumbricus sp.) in the three locations with size of the sampling area at each location was $1 \times 1 \mathrm{~m}$ with a depth of 0-30 $\mathrm{cm}$ and the supporting sample for this study was the soil where earthworms were found.

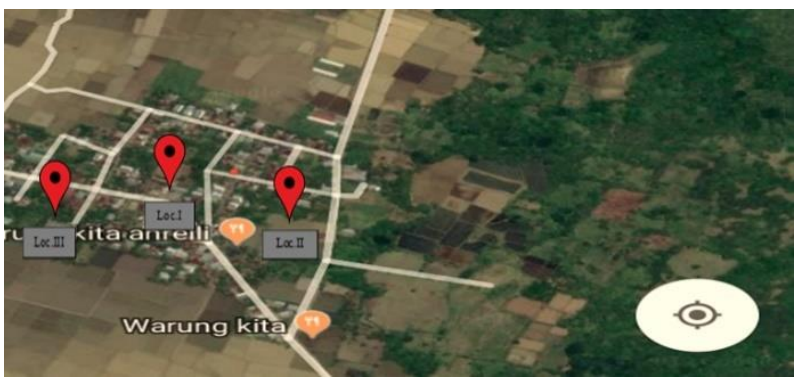

Figure 1 Map of research locations.

The sampling technique used purposive sampling, where the worms found were identified and described. The sampling method is Hand-Sort (direct taking) using the tools and materials that have been provided as in table 1 and 2 as an instrument in obtaining and 
measuring worms and supporting samples in the form of identifying the physical, chemical, and biological conditions of the soil using the Morario formula. The research procedure consisted of three stages, namely the preparation stage, the implementation stage, and the Earthworm identification stage. The data analysis technique is descriptive-qualitative with an inductive approach to identify and describe Earthworms on the subject of the Animal World with sub-material "knowing invertebrates" and sub-material

\subsection{Tool}

Table 1. List of tools and its function

\begin{tabular}{|l|l|}
\hline \multicolumn{1}{|c|}{ Tool } & \multicolumn{1}{c|}{ Function } \\
\hline Hoe & Used for the retrieval of earthworms. \\
\hline Meters & Used to measure the depth and length of the body. \\
\hline Pingset & Used to pick up earthworms during the identification. \\
\hline Camera & Used to take pictures on site. \\
\hline Scales & Used to weigh soil weight. \\
\hline Thermometer & Used to measure air temperature at the location. \\
\hline Measuring cup $300 \mathrm{ml}$ & Used to calculate the amount of soil per sample. \\
\hline Wok & Used to roast the soil to be calculated soil moisture content. \\
\hline Microscope & Used to observe earthworm morphology. \\
\hline
\end{tabular}

\subsection{Material}

Table 2. List of materials function

\begin{tabular}{|l|l|}
\hline \multicolumn{1}{|c|}{ Material } & \multicolumn{1}{c|}{ Function } \\
\hline Plastic & Used as a sample container when at the research location. \\
\hline Alcohol $70 \%$ & Used to clean and preserve earthworms. \\
\hline Stationery & Used for write down each item to be researched. \\
\hline Universal Indicators & Used to measure soil pH. \\
\hline
\end{tabular}

\section{RESULTS AND DISCUSSION}

\subsection{Potency of Earthworms (Lumbricus sp.)}

Based on the results, the topography of the three research locations is lowland and still in rural conditions so that many trees and other plants are "classification systems" (natural classification systems, artificial classification, and phylogenic classification) Senior High School (SMA) class X according to Core Competencies (KI.3) and Basic Competencies (KD.3.3), which explains the principles of classification of living things in five kingdoms. As for the eligibility criteria for learning resources through feasibility tests by experts, namely teaching materials and media experts using expert validation sheets and expert response questionnaires 
Table 3. Comparison of morphological features of Lumbricus sp., found.

\begin{tabular}{|l|c|c|c|}
\hline \multirow{2}{*}{ Morphology } & \multicolumn{2}{c|}{ Lumbricus sp. } \\
\cline { 2 - 4 } & Lumbricus terresrtis & Lumbricus castaneus & Lumbricus rubellus \\
\hline Size & $210 \mathrm{~mm}$ & $160 \mathrm{~mm}$ & $240 \mathrm{~mm}$ \\
\hline Body color & Red & Reddish-brown & Pink \\
\hline Number of Segments & 130 & 43 & 200 \\
\hline Setae type & Rod & Rod & Rod \\
\hline Clitelium color & Reddish-brown & Pink & Young Orange \\
\hline Prostomium type & Tanylobus & Tanylobus & Tanylobus \\
\hline
\end{tabular}

Table 4. Environmental parameter measurement results.

\begin{tabular}{|l|c|c|c|}
\hline \multirow{2}{*}{} & \multicolumn{3}{c|}{ Location } \\
\cline { 2 - 4 } & Parameters & II & III \\
\hline Air temperature ${ }^{0} \mathrm{C}$ & 24.5 & 28 & 6 \\
\hline Soil pH & $7^{*}$ & 6 & 8.9 \\
\hline Soil water content \% & 9.1 & 5.9 & Clay loam \\
\hline Soil texture & Clay loam & Sandy loam & \\
\hline
\end{tabular}

Description: Highest value (*), settlement (location I), rice fields (location II), cattle ranch (location III)

\subsubsection{Location of Residential Areas}

The research findings on the location of the residential areas found a type of Lumbricus terrestris presented in figure 2, its morphological characteristics can be seen in table 1, where the species of Lumbricus terrestris found has a body size with a length of 210 $\mathrm{mm}$ at a depth of $11 \mathrm{~cm}$. The average body color of brown-reddish, pink, and red looks pale. This discovery is almost the same as found in other locations, where the average body color looks brown mixed with red, but the color in the whole body is more dominated red color and slippery skin surface. It is influenced by pigment differences and the presence of hemoglobin from the surface zone of the body. On the surface of the body (figure 2.a), there are segments with a total of 130 segments. The type of setae found has a rod shape that is located on each curve of the segment edge. In the body part (figure 2.b) there is 1 klitelium in the form of a granduler structure (bulge), in which the color of the klitelium looks reddishbrown which is a slightly different color to the surface of the body. While the front part there is a prostomium or mouth lobe (figure 2.c) that has a type of tany lobus at the end of the mouth with a groove separation as thick as 1 segment. The tip of the body is the anus (figure 2.d) of the Lumbricus terrestris.
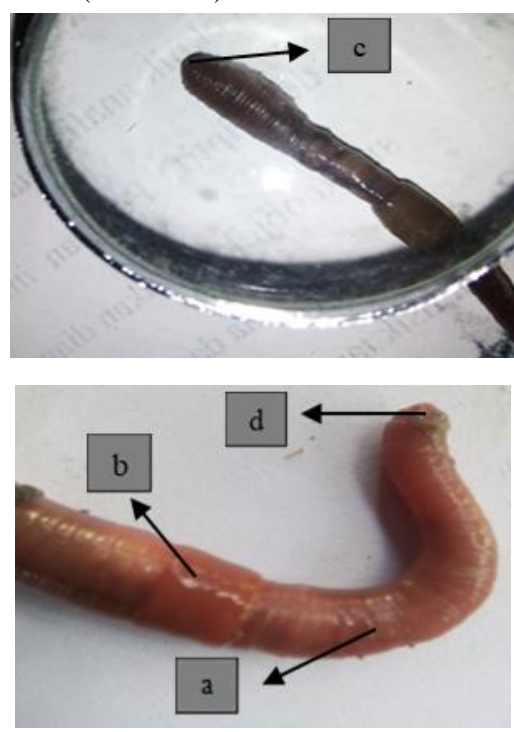

Figure 2 Lumbricus terrestris; a. segment, b. clitelium, c. prostomium (tanylobus), d. ends of the body (anus).

The air temperature at this location is $24.5^{0} \mathrm{C}$, where it is still in an optimum state. Soil $\mathrm{pH}$ measurement was found at the value of 7 . The $\mathrm{pH}$ size value in this location is higher when compared to the $\mathrm{pH}$ size in the other two research locations. Another factor is the condition of groundwater content that is still in good condition for worm activity, where the parameters of groundwater content obtained are $9.1 \%$. 
While the texture of the soil is clay loam which is also a contributing factor to the well growth of earthworms.

\subsubsection{Location of Rice Field}

The research findings at this location found a type of Lumbricus castaneus, where the average found has a morphology with a body size of $160 \mathrm{~mm}$ at a depth of $13 \mathrm{~cm}$, and the body size at this location is shorter than the location of residential areas and cattle farms. This is influenced by environmental factors that are less supportive at the time of sampling with rice fields that lack water and organic matter. Another influencing factor is the air temperature that makes this location hot. The overall body color, especially near the anus, has a reddish-brown color, but it looks pale and the surface of the body is transparent and rough (figure 3). It is influenced by factors of the type of Lumbricus castaneus itself and soil moisture. Too high soil moisture causes worms to be pale in color and even experience death. Conversely, if the humidity is too low, the earthworm will move to the humid media because the environmental temperature is very influential on metabolic activity, growth, respiration, and production, so that the temperature is too high or too low will be very disruptive to the physiology of earthworms. The body of Lumbricus castaneus (figure 3.a) has a segment spread in the form of lines on the surface of the body called segments with total 43 segments. Segments are scattered on the posterior (back), anterior (front), and part of the segment there is setae, where the observations are found setae on the surface of the body that has a type shaped like a trunk (figure 3.b) in each curve of the surface of the body arranged in a ring around the periphery of each segment both on the anterior, and posterior. The location of the klitelium (figure 3.c) is located after the $15^{\text {th }}$ segment that is elongated and has a different color with a pink body color that is similar to the pale surface color of the body. The front part (figure 3.d) is a tanylobus-shaped prostomum in the form of a protrusion that serves as a place for foreign objects to attach. This form is commonly found in the genus Lumbridae, where the prostomium extends forward almost like epilobus caused by its separation grooves up to as thick as segment 1.

At this location the highest air temperature is 28 ${ }^{\circ} \mathrm{C}$, the high temperature is caused by environmental factors that are rarely found in high trees that trigger high sun heat. However, the soil $\mathrm{pH}$ is optimum which is the size value of $\mathrm{pH}$ 6. Groundwater content at this location is $5.9 \%$ so that it affects the condition of earthworms caused by lack of water. Another factor that does not support the growth and development of earthworms is the texture of the soil which has form of sandy loam. This is because the water used for rice fields mixed with sand so that for a long period of time, the soil in the location mixed with sand so that it causes food sources to decrease and impact the population, growth, and development of earthworms in the environment.

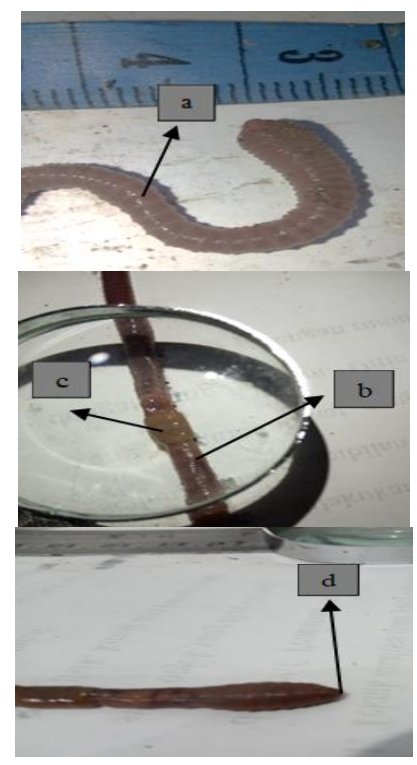

Figure 3. Lumbricus castaneus; a. segment distribution, b. setae, c. clitelium, d. prostomium (tanylobus).

\subsubsection{Location of Cattle Farms}

The results of research at this location found a type of Lumbricus rubellus that on average has a body size with a body length of $240 \mathrm{~mm}$ at a depth of $10 \mathrm{~cm}$. The surface of the body has a pink color that is almost towards the pink color and a slippery surface of the body. This is influenced due to differences in pigments and hemoglobin from the surface zone of the body. Each side of the body has a segment spread in the form of lines on the body of earthworms and each segment (figure 4.a) Lumbricus rubellus is found to have 200 segments. Supporting factors of different segments of residential and rice field locations, namely due to environmental factors consisting of air temperature, soil $\mathrm{pH}$, groundwater content, and soil texture. In this segment, there are setae (figure 4.b) on the skin that has a rod-like shape. After the $15^{\text {th }}$ segment, there is a clitelium (figure 4.c) that extends in light orange and differs from the surface color of its body. The location of the prostomium (mouth lobe) obtained (figure 4.d) is on the front end of the body in the form of a tanylobus that is planted with the presence of an elongated front forward that is almost similar to the 
epilobus but the separation groove is deep to the thickest of segment 1 .
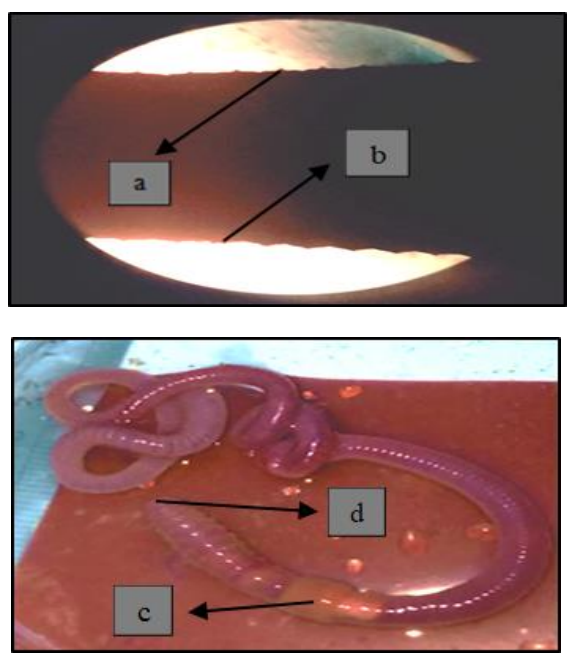

Figure 4. Lumbricus rubellus; a. segment distribution, b. setae, c. clitelium, d. prostomium (tanylobus)

The air temperature measurement at this location is $24{ }^{\circ} \mathrm{C}$, which is classified as optimum. Soil $\mathrm{pH}$ measurement was found the value of the measurement result of 6 , the $\mathrm{pH}$ size value at the location of this cattle farm is equal to the $\mathrm{pH}$ value in rice fields and low when compared to the $\mathrm{pH}$ size in residential locations. Measurements of groundwater content alone found a yield of $8.9 \%$ and the texture of the soil is clay loam, where it supports the growth and development of Earthworms. Another factor is due to cow dung which makes the soil on-site moist.

Based on the results and discussions related to size, body-color, number of segments, type of setae, the color of the clitelium, and type of prostomium, the findings are in line with findings of Fitri [11], where the Lumbricus terrestris worm has a body size of 87$137 \mathrm{~mm}$, and according to Hanafiah [12], Lumbricus castaneus and Lumbricus rubellus have a body size of 25-105 mm. Febrita [8], states that the increasing length of the body of Earthworms can be observed on the posterior part of the worm, namely the presence of brighter segments with shorter segments compared to other segments. Hanafiah [12], states that if the body is red, brown or pink, this can be affected by the thickness of the skin. The number of bodies of Lumbicus terrestris and Lumbricus castaneus is 60110 segments. While Lumbricus rubellus has a general number of segments of 26, (27-32). According to Hanafiah [12], the shape of the type is setae Lumbricus sp., depending on the type or species, in which the setae is arranged inside a ring around the periphery of each segment. The difference in the color of clitelium in Lumbricus sp., according to Hanafiah [12], is the presence of green chlorogagen cells close to the surface and worms that are red or pink due to hemoglobin from the surface zone of capillary vessels. While the prostomium type of the species Lumbricus terrestris, Lumbricus castaceus, and Lumbricus rubellus, in general, has a type of tanylobus, but is almost the same as the epilobus type, only the separation groove is in the thickest of segments [12].

Similar research related to the measurement of environmental parameters in the form of air temperature, soil $\mathrm{pH}$, groundwater content, and soil texture that is according to Nurrohman [13], earthworms can live in optimum areas of $10-20^{\circ} \mathrm{C}$, while according to Febrita [8], the environmental temperature required by Earthworms for growth ranges from $15-25^{\circ} \mathrm{C}$ and temperatures higher than $25^{\circ} \mathrm{C}$ are still good for the growth of earthworms when the humidity is supportive. The difference was influenced by the environment at the time of observation, one of which is the scorching heat of the sun. The measurement of $\mathrm{pH}$ according to Hanafiah [12], soil acidity greatly affects the number of worms and all activities, and generally, earthworms grow well at a $\mathrm{pH}$ of about 7,0 . On the contrary, according to Brata [14], earthworms are rare in soils with a $\mathrm{pH}$ below 4, since the optimum acidity $(\mathrm{pH})$ for earthworms is $6,8-7,2$. According to Jayanthi [15], to maintain the water content in the body of earthworms, soil moisture is needed for the respiratory process. Whereas according to Febrita [8], good humidity for earthworms is between $15 \%-50 \%$. Moist media usually contains high enough oxygen so that the process of oxygen capture by the body can take place properly. Reduced soil organic matter which means at least the supply of earthworm feed so that for the long term will cause earthworms to leave the land or experience death [8].

\subsection{Correlation of Earthworm Morphologies as Biology Learning Resource}

Learning resources are an important part of supporting the learning process. Student activeness in the teaching and learning process is certainly also inseparable from the learning resources used to trigger the interest and spirit of students in learning. In addition, the use of good learning resources for teachers can provide convenience to students in obtaining a number of information, knowledge and skills in the teaching and learning process. According to Khanifah [16], learning resources are utilized for the benefit of the teaching and learning process, either directly or indirectly, in part or in whole. Therefore, 
based on the results of research to integrate the discoveries of earthworm species in this study as a learning resource, researchers emphasized on providing direct experience to students to develop character formation competencies of environmental care by learning directly to identify and describe the morphology of earthworm species in three locations as an environmental-based biology learning resource.

The utilization of the environment as a biology learning resource is inseparable from the integration of biological sciences, where this research correlates biology learning by utilizing the environment to study the subject matter of the Animal World. The learning resource described in the results of this study is direct learning in the environment to identify and describe earthworms in the subject of World Animal at senior high school in $10^{\text {th }}$ grade. In accordance with the purpose of the research, namely (1) to know the morphological potential of earthworms (Lumbricus sp.) in residential areas, rice fields, and cattle farms in Anrelli Village, Kulo District as a source of learning, and (2) to know the morphological potential of earthworms (Lumbricus sp.) in supporting the process of learning biology by utilizing the environment as a source of learning. Therefore, the results of research in the form of morphological potential of Earthworms will be integrated with environmental-based learning resources on the subject of Animal World according to KI. 3 KD. 3.3 and KI.4 KD. 4.3.

Morphological observations of earthworms by utilizing the environment as a learning resource will interest students to be able to dig information directly, because observations related to invertebrate animals both from physical properties in the form of size, shape, characteristics and other physical will train students to process well in learning to recognize and see directly the related observed. Yazdi [17], also said that in learning activities students not only imitate and imagine of what the teacher observes or teaches, but actively selects, filters, gives meaning, and tests the truth of the information it receives. The existence of three types of earthworms found to be a reference source of learning will also facilitate students in obtaining information and will train their social skills in learning together, be it individual learning for training analyze ability, and well it is group learning to train social attitudes to solve problems together. So that the role of learning resources becomes one of the important things to increase student interest in order to support their learning spirit that sometimes makes students tired of learning with that learning resource alone (monotonous) or using only one learning environment (classroom) without varying the student's learning environment.
The results of research to make the potential of earthworm morphologies as a source of study found three types of Lumbricus sp., in three locations namely settlement (location I) found Lumbricus terrestris and Lumbricus castaneus, rice fields (location II) found Lumbricus castaneus, and cattle farms (location III) found Lumbricus castaneus and Lumbricus rubellus. The discovery of three types Lumbricus sp., in this study can help students in learning to directly identify and describe earthworms on the subject matter of animal world with sub material "know invertebrate animals" and sub material "classification system" at senior high school in $10^{\text {th }}$ grade. The three research locations in its application as a learning resource in knowing the animal world according to KI. 3 KD. 3.3 and KI.4 KD. 4.3, students will be introduced related to invertebrate animals and the system of three classification systems, namely the first natural classification system, in the form of grouping based on morphological characteristics. Both artificial classifications, in the form of groupings based on easyto-see morphological features, are either influenced by artificial and or human interactions, and or based on their artificial. The three classifications are phylogenic, in the form of groupings that pay attention to the history of evolution or the history of living beings. There are several benefits by making the research location as a learning resource for students based on this environment, namely responsible personal, strengthening the bond of friendship between students, fostering a sense of care for fellow friends and the environment, training students to think creatively, capablely, and many others. The statement is in line with Imtihana [4], that students can know the problems that occur in their environment through the information. Once the student knows the problem, there is concern for the student. This concern leads students to analyze and find solutions that can be used to solve the problem. Other statements are similar to Sardiman [18], the advantages in utilizing the environment as a learning resource is to make students get information based on direct experience, more communicative, make lessons more concrete, make students know and love the environment, and the application of science becomes easier in accordance with the problems faced in their daily lives.

\section{CONCLUSION}

Based on the results of research on the potential of earthworms (Lumbricus sp.) as a source of environment-based biology learning, it is concluded that the three locations in this study, namely settlements (location I), rice fields (location II), and cattle farming (location III) can be used as an 
environment-based learning resource for class 10 Senior High School (SMA). The potential morphology of Earthworm species found in the three locations, namely Lumbricus terrestris, Lumbricus castaneus, and Lumbricus rubellus. Observations of earthworm's morphology that can be observed by students as a learning resource are body size, skin/body surface, body-color, segment, type of setae, klitelium, and prostomium, as well as environmental parameter conditions such as air temperature, soil $\mathrm{pH}$, soil water content, and soil texture. Meanwhile, to support biology's learning process by utilizing the environment as a learning resource, namely the environmental conditions itself that can be reached easily. As for the constraints of this study, namely the environmental conditions in the form of unfavorable weather and the soil in the rice fields experiencing water shortages due to the dry season, several research locations that have been determined for sampling are challenging to find Earthworms. Therefore, if the research location is to be fully utilized as an environment-based learning resource, it is better to make observations and control the land that the students want to observe.

\section{REFERENCES}

[1] S. Syamsudduh, M. Rapi, Penggunaan Lingkungan Sekolah sebagai Sumber Belajar Dalam Meningkatkan Hasil Belajar Biologi, Lentera Pendidikan, Journal Ilmu Tarbiyah dan Keguruan 15(1) (2012) 18-31. DOI: https://doi.org/10.24252/lp.2012v15n1a2

[2] Mudhoffir, Principles of Learninng Resource Center Management, Remaja Rosdakarya, 1992.

[3] T.M. Duffy, D.H.A. Jonassen, Constructivism and The Technology of Instruction, Hillsdale, New Jersey, Lawrence Erbaum Associates, 1992.

[4] M. Imtihana, F.P. Martin, B. Priyono, Pengembangan Buklet Berbasis Penelitian sebagai Sumber Belajar Materi Pencemaran Lingkungan di SMA, Journal Biology Education 3(2) (2014) 186-192.

[5] D.A. Vikagustanti, Sudarmin, S.D. Pamelasari, Pengembangan Media Pembelajaran Monopoli IPA Tema Organisasi Kehidupan sebagai Sumber Belajar untuk Siswa SMP, Unnes Science Education Journal 3(2) (2014) 468-475.

[6] D. Haryati, Efektivitas Pemanfaatan Lingkungan Sekolah sebagai Sumber Belajar terhadap Hasil Belajar IPA Peserta Didik Kelas IV SD Inpres
BTN IKIP I Makassar, Journal Pendidikan Dasar Islam 3(2) (2016) 80-96.

[7] Safei, Learning Media Definition, Develpoment, and Application Print 1, Alauddin University Press, 2011.

[8] E. Febrita, Darmadi, E. Siswanto, Pertumbuhan Cacing Tanah (Lumbricus rubellus) dengan Pemberian Pakan Buatan untuk Mendukung Proses Pembelajaran pada Konsep Pertumbuhan dan Perkembangan Invertebrata, Journal Biogenesis 11(2) 2015 169-176.

[9] D.S. Pangestika, Nurwidodo, L. Chamisijatin, Pengaruh Pemberian Pakan Limbah Baglog Jamur Tiram Putih (Pleurotus ostreatus) dan Kotoran Ayam terhadap Pertumbuhan dan Belajar Biologi, Journal Pendidikan Biologi Indonesia 2(2) 2016 168-179.

[10] N.S. Sukmadinata, Educational Research Methods, Remaja Rosdakarya, 2013.

[11] N. Fitri, Q. Nida, S. Mulyono, Populasi Cacing Tanah di Kawasan Ujung Seurudong Desa Sawang Ba'U Kecamatan Sawang Kabupaten Aceh Selatan, in: Prosiding Seminar Nasional Biotik, vol 2, 2015, pp. 187-189.

[12] K.A. Hanafiah, Soil Biology: Soil Ecology and Macrobiology, Raja Grafindo Persada, 2013.

[13] E. Nurrohman, A. Rahardjanto, S. Wahyuni, Keanekaragaman Makrofauna Tanah di Kawasan Perkebunan Coklat (Theobroma cacao L.) sebagai Bioindikator Kesuburan dan Sumber Belajar Biologi, Journal Pendidikan Biologi Indonesia 1(2) (2015) 197-208.

[14] B. Brata, Pengaruh Beberapa Campuran Media pada Feses Sapi Kaur yang Diberi Pakan Rumput Setaria dan Pelepah Sawit terhadap Biomassa dan Kualitas Vermikompos Cacing Tanah Pheretima sp, Journal Sains Peternakan Indonesia 12(2) (2017) 142-151. DOI: https://doi.org/10.31186/jspi.id.12.2.142-151

[15] S. Jayanthi, R. Widhiastuti, E. Jumilawaty, Komposisi Komunitas Cacing Tanah pada Lahan Pertanian Organik dan Anorganik di Desa Raya Kecamatan Berastagi Kabupaten Karo, Journal Ilmiah Biologi Teknologi dan Kependidikan 2(1) (2014) 1-9. DOI: https://doi.org/10.22373/biotik.v2i1.228

[16] S. Khanifah, K.K. Pukan, S. Sukaesih, Pemanfaatan Lingkungan Sekolah sebagai 
Sumber Belajar untuk Meningkatkan Hasil Belajar Siswa, Unnes Journal Biology Education 1(1) (2012) 66-73.

[17] M. Yazdi, E-learning sebagai Media Pembelajaran Interaktif Berbasis Teknologi Informasi, Journal Ilmiah Foristek 2(1) (2012) $143-152$.

[18] Sardiman, Media Education, Raja Grafindo Persada, 2005. 